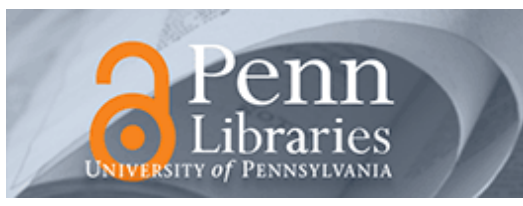

University of Pennsylvania ScholarlyCommons

2003

\title{
Institutional Investor Preferences and Price Pressure: The Case of Corporate Spin-Offs
}

Jeffery S. Abarbanell

Brian J. Bushee

University of Pennsylvania

Jana Smith Raedy

Follow this and additional works at: http://repository.upenn.edu/accounting_papers Part of the Accounting Commons

\section{Recommended Citation}

Abarbanell, J. S., Bushee, B. J., \& Raedy, J. (2003). Institutional Investor Preferences and Price Pressure: The Case of Corporate SpinOffs. Journal of Business, 76 (2), 234-261. http:// dx.doi.org/10.1086/367749 


\section{Institutional Investor Preferences and Price Pressure: The Case of Corporate Spin-Offs}

Disciplines

Accounting 


\title{
Jeffery S. Abarbanell
}

University of North Carolina

\author{
Brian J. Bushee \\ University of Pennsylvania
}

Jana Smith Raedy

University of North Carolina

\section{Institutional Investor Preferences and Price Pressure: The Case of Corporate Spin-Offs*}

\section{Introduction}

Prior research conjectures that trading caused by investor preferences can result in price movements (both temporary and permanent) around major corporate events. For example, Shleifer (1986) finds evidence of positive abnormal returns earned by stocks immediately after entering the Standard and Poor's 500 Stock Index (S\&P 500), which he argues is caused by intense buying by index funds in response to the listing event. Vijh (1994) reports a 3\% abnormal return around the ex dates of spin-off transactions for the combined parent and subsidiary (sub). He conjectures that this return may be driven by certain investor cli-

* We would like to thank Walt Blacconiere, Tom Dyckman, Ed Maydew, Kevin Raedy, Jerry Salamon, Katherine Schipper, Jim Seida, Jim Wahlen, Marc Zenner, an anonymous reviewer, and workshop participants at the 1998 Financial Economics and Accounting Conference, Cornell University, Harvard University, Indiana University, the Massachusetts Institute of Technology, Stanford University, University of North Carolina/Duke Fall Camp, the University of Chicago, the University of Pennsylvania, the University of Rochester, and Yale University for helpful comments and suggestions. We would also like to thank Michelle Yetman for her research support.

(Journal of Business, 2003, vol. 76, no. 2)

(C) 2003 by The University of Chicago. All rights reserved. 0021-9398/2003/7602-0002\$10.00
Corporate spin-offs create new firms with characteristics markedly different from the original firm. Consequently, institutional investors precommitted to certain investment styles or subject to fiduciary restrictions have incentives to rebalance their portfolios at the time of the spin-off. We find strong evidence that investment strategy and fiduciary restrictions affect institutional investor demand for stocks after spin-offs. However, contrary to prior research conjecturing that trading related to investor preferences creates short-term price pressure in entities emerging from spin-off transactions, we find that, in general, this trading is not associated with abnormal price movements for parents or subsidiaries around the spin-off. 
enteles that wait until after a spin-off becomes effective to buy a now-desirable post-spin-off entity and that willingly pay a premium to compensate sellers for holding the stock until the spin-off becomes effective. Brown and Brooke (1993) argue that noninformational trades by institutions are responsible for price declines of approximately $4 \%$ in spin-off subsidiaries in the 30 days subsequent to a spin-off transaction. However, in documenting these price effects, none of these studies present direct evidence of preference-induced trading around the event or that such trading is associated with the observed price movements.

The purpose of this article is to provide direct evidence as to whether corporate spin-offs lead to preference-induced trading on the part of institutional investors around the spin-off event and whether this trading is associated with the previously observed abnormal price movements in the parents or subsidiaries. Corporate spin-offs are a powerful setting to examine the role of investor preferences because spin-offs generally create entities whose economic characteristics differ markedly from the original firm. If large blocks of investors adhering to similar criteria for selecting stocks receive shares of newly spun-off entities that no longer meet those criteria, the ensuing portfolio rebalancing has the potential to create price movements. ${ }^{1}$ These potential price movements may be temporary (resulting from pressures) or permanent (resulting from downward-sloping demand curves). While some studies provide evidence consistent with institutional trading causing short-term price pressures (Harris and Gurel 1986; Lynch and Mendenhall 1997), results from other studies are consistent with institutional trading causing a shift in the supply curve and thus a price movement because of downward-sloping demand curves (Shleifer 1986; Kaul, Mehrotra, and Morck 2000; Gompers and Metrick 2001). ${ }^{2}$ Alternatively, the price movements observed around corporate spin-offs may not result from preference-based institutional trading. If there is enough variation in investment preferences or adequate competition among investors whose trades are not constrained, trading motivated by these preferences could have no perceptible pricing effects in spin-off firms.

The first step in our approach is to test whether spin-offs cause institutional investors to rebalance their portfolios based on the fiduciary restrictions they face or the investment styles to which they have precommitted. Based on the work of Del Guercio (1996) and Lang and McNichols (1997), we divide institutions into four groups-bank trusts, insurance companies, investment advisors (including mutual fund companies), and pensions and endowments - to capture differences in the strictness of the fiduciary standards faced by the institutions. Bank trusts and pensions and endowments face the most

1. We focus on institutional investors because they have become the dominant equity holder in the U.S. market, they exhibit significant differences in investment strategies and exposure to fiduciary standards, and they often trade in blocks that many market observers claim are large enough to cause price pressure (Chan and Lakonishok 1993).

2. Ofek and Richardson (2000) utilize the shift in supply of stocks resulting from the end of the IPO lock-up period to provide evidence that stocks have a downward sloping demand curve. 
stringent fiduciary standards, as they are governed by common law and Employees Retirement Income Security Act rules requiring that each investment be considered prudent in isolation. By contrast, insurance companies and investment advisors have historically been free from any legal pressure to maintain strict standards of prudence (Del Guercio 1996).

Del Guercio (1996) demonstrates that differences in the strictness of fiduciary standards between banks and mutual funds affect the composition of their cross-sectional holdings. This evidence suggests that fiduciary standards potentially create incentives to rebalance holdings in response to major changes in firm characteristics after the effective date of a spin-off. Whether these incentives outweigh the costs related to transactions, including suboptimal timing of capital gains taxation, and cause institutions to alter their holdings in response to a spin-off are empirical questions. Therefore, our analysis of changes in institutional holdings extends the work of Del Guercio (1996) by examining the magnitude and speed with which the various institutional types rebalance their holdings in response to changes in the fundamental characteristics of firms in their portfolio. We find evidence that institutions subject to stringent fiduciary restrictions rebalance their portfolios immediately after the spin-off consistent with binding fiduciary standards.

We also test whether classifying institutions based on their "investment styles" or revealed preferences for firms with certain characteristics (e.g., large market capitalization or high growth) predicts portfolio rebalancing activities in response to spin-offs. Institutions tend to adopt investment styles both to guide their investment decisions and to attract a stable investor base that seeks investment in firms targeted by the style (O'Barr and Conley 1992). We use factor analysis and cluster analysis to classify institutions into four groups-large-value, largegrowth, small-value, and small-growth-based on their past investment preferences for value versus growth firms and large-cap versus small-cap firms. This approach assumes that explicit and implicit contracts between institutional investors and their clients specify investment preferences for stocks that are reflected in institutions' past trading behavior and will be reflected in future trading decisions.

As in the case of fiduciary standards, it is an empirical issue whether the threat of fund sponsor action against institutions holding stocks inconsistent with their style is sufficiently strong to offset the costs of rebalancing after a spin-off. We find evidence that institutional investor trading around spin-offs is sensitive to investment styles. For instance, institutions following largevalue styles significantly reduce their holdings in subs, whereas institutions following small-growth styles significantly increase their holdings in subs after spin-offs.

Having established an association between institutional preferences and changes in their holdings in response to spin-offs, we next examine abnormal returns over short intervals around the effective date of a spin-off to determine whether, as conjectured in prior research, the trading induced by adherence to investment styles or fiduciary standards is associated with price move- 
ments. ${ }^{3}$ In general, we find very little evidence consistent with price movements resulting from institutional trading around spin-offs. For spin-off parents, the only evidence that we find of price movements that are associated with changes in institutional investor holdings is for institutions following small-growth styles that purchase post-spin-off parents that are below median size. However, the returns related to this pressure are small and insufficient to explain ex date abnormal returns documented by Vijh (1994). Similarly, for spin-off subs, we find little evidence that preference-induced institutional investor trading is associated with the temporarily depressed sub prices after spin-offs reported by Brown and Brooke (1993).

There are several possible reasons why we may not be able to detect price movements associated with institutional trading in our study. First, because our data do not permit exact matching between institutional holdings and return intervals, a potential criticism is that our tests lack the power to find an association between institutional trading and short-window returns because of measurement error in quarterly changes in institutional holdings. To alleviate this concern, we demonstrate that our quarterly change in institutional holdings variables is significantly associated (in the expected direction) with abnormal trading volume in parents and subs on days that abnormal returns are also observed. Reverse regressions produce results consistent with the original regression results, suggesting that measurement error in the change in holdings is not a complete explanation for the lack of significant returns. Second, since many spin-off transactions trade on a "when-issued" basis prior to the effective date, we also run the analyses including the when-issued trading period where relevant and find that results are unaltered. Finally, we examine the possibility that preference-induced price pressure in parents and subs only exists when the spun-off entities have characteristics very different from the combined entity or the institution must buy or sell large blocks to establish its new desired holdings level. This refinement leads to only limited evidence of price movements associated with institutional investor trading.

Our results contribute to the literature on the behavior and preferences of institutional investors, providing a quantitative analysis of the effects of selfimposed investment styles and externally imposed fiduciary standards on their trading. This article also contributes to the literature on price pressure from noninformation-based trading, with the added distinction that it is, to our knowledge, the only study that directly tests for the phenomenon around significant equity restructuring events. Moreover, we reconfirm the presence of two pricing anomalies associated with spin-offs identified in prior literature and provide evidence that preference-based trading reflected in changes in institutional investor holdings does not fully account for them (Brown and Brooke 1993; Vijh 1994).

3. We define the effective date as the first date the spun-off entities begin trading, which corresponds to the ex date for all parents and the majority of subs (a few subs begin trading up to 12 trading days after the ex date). 
The remainder of the article is organized as follows: our spin-off sample is described in Section II along with a description of how institutions are classified by fiduciary standards and by investment style. Section III presents our main empirical tests and results. Section IV reports various sensitivity analyses. Section V presents a summary and conclusions.

\section{Data and Variable Definitions}

\section{A. Sample Selection}

Our tests are based on a sample of 169 spin-off transactions with all necessary data between 1980 and 1996. A search of the Securities Data Company (SDC) Platinum mergers and acquisitions database for completed domestic spin-offs between January 1, 1980, and December 31, 1996, yielded 408 transactions. Forty-five observations were deleted because stock distributions were made to parties other than existing shareholders. Another 44 observations were deleted because the distributions were less than $80 \%$ of the equity in the sub (precluding tax-free treatment). Ten observations were deleted because the percentage of shares distributed was not indicated, bringing the sample size to 309. These sample transactions were verified using the $\mathrm{CCH}$ Capital Changes Reporter. At this point, 14 observations were eliminated because we were unable to verify or adjust announcement dates and effective dates in the original SDC database on Lexis-Nexis or the Wall Street Journal Index. Finally, 60 observations were deleted because the parent or sub was acquired or taken private as part of the spin-off transaction, leaving 235 transactions. By eliminating these observations, we preclude the possibility of return effects driven by takeover premia (Cusatis, Miles, and Woolridge 1993).

We collected stock price, return, and total shares outstanding from the 1997 Center for Research in Security Prices (CRSP) daily New York Stock Exchange, American Stock Exchange, and NASDAQ files. Twenty-four firms (mostly foreign or very small firms) were eliminated because of missing CRSP data. All other variables (except institutional holdings data) were obtained from the 1997 Compustat files; missing Compustat data reduced the sample by a further 32 firms. The remaining sample was matched with institutional holdings data from the Spectrum database, which contains all 13f filings between 1980 and 1997. According to Security and Exchange Commission Rule 13f, all institutions managing more than $\$ 100,000,000$ in equity must file a quarterly report listing all equity holdings that are greater than 10,000 shares or $\$ 200,000$ in market value. Thus, for each firm, total institutional holdings are defined as the sum of all end-of-calendar-quarter holdings by fund managers filing 13f's on the firm. Missing Spectrum data reduced the sample size by 10 firms, producing a final sample of 169 transactions.

Table 1 presents descriptive statistics of the final sample. Means and medians of various firm characteristics are presented along with significance tests of the differences in the combined firms, parents, and subsidiaries. Parents are 
TABLE 1 Descriptive Statistics of the Spin-Off Sample

\begin{tabular}{|c|c|c|c|c|}
\hline & & $\begin{array}{l}\text { Pre-Spin-Off } \\
\text { Firm }\end{array}$ & $\begin{array}{l}\text { Post-Spin-Off } \\
\text { Parent }\end{array}$ & $\begin{array}{l}\text { Post-Spin-Off } \\
\text { Sub }\end{array}$ \\
\hline \multirow[t]{2}{*}{ Market value of equity } & Mean & $2,893,536$ & $2,841,399$ & $716,176^{*^{+}}$ \\
\hline & Median & $1,177,325$ & 832,139 & $159,174 *^{+}$ \\
\hline \multirow[t]{2}{*}{ Total assets } & Mean & $4,295,044$ & $4,005,830$ & $875,451^{*+}$ \\
\hline & Median & $1,467,903$ & $1,228,762$ & $224,506^{*+}$ \\
\hline \multirow[t]{2}{*}{ Total sales } & Mean & 700,835 & 665,308 & $166,533^{*^{+}}$ \\
\hline & Median & 254,500 & 260,473 & $61,924 *^{+}$ \\
\hline Indicator for S\&P500 & Mean & .506 & .459 & $.105^{*+}$ \\
\hline Membership & Median & 1.000 & .000 & $.00 *^{*+}$ \\
\hline \multirow{2}{*}{$\mathrm{S} \& \mathrm{P}$ stock rating } & Mean & 4.439 & 3.993 & $.000^{*+}$ \\
\hline & Median & 5.000 & 5.000 & $.000 *^{+}$ \\
\hline \multirow[t]{2}{*}{ Book value/price } & Mean & .476 & .505 & $.854^{*+}$ \\
\hline & Median & .443 & .428 & $.650^{*+}$ \\
\hline \multirow[t]{2}{*}{ Earnings/price } & Mean & .030 & .043 & $.00 *^{+}$ \\
\hline & Median & .039 & $.057^{*}$ & $.037^{+}$ \\
\hline \multirow[t]{2}{*}{ Dividend yield } & Mean & .019 & .021 & $.008^{*+}$ \\
\hline & Median & .018 & .018 & $.000^{*+}$ \\
\hline \multirow[t]{2}{*}{ Return on equity } & Mean & .079 & .102 & $.029^{*+}$ \\
\hline & Median & .103 & $.126^{*}$ & $.057^{*+}$ \\
\hline \multirow[t]{2}{*}{ Debt-equity } & Mean & .363 & $.684 *$ & $.541 *$ \\
\hline & Median & .230 & .285 & .304 \\
\hline \multirow[t]{2}{*}{ Beta } & Mean & 1.151 & 1.151 & 1.197 \\
\hline & Median & 1.148 & 1.146 & 1.132 \\
\hline \multirow{2}{*}{$\mathrm{SD}$ of returns } & Mean & .098 & .100 & $.128 *^{+}$ \\
\hline & Median & .090 & .091 & $.113^{*+}$ \\
\hline
\end{tabular}

Note. - Sub $=$ subsidiary. This table presents the means and medians of various firm characteristics for the pre-spin-off firms, the post-spin-off parents, and the post-spin-off subs. Pre-spin-off data are measured at the last calendar quarter end prior to the spin-off. Post-spin-data are calculated 1 year after the spin-off to allow for the computation of accounting-based ratios and stock market variables. The market value of equity, total assets, and total sales is measured in thousands. The S\&P stock rating is converted to numerical values, with $\mathrm{A}+=9, \mathrm{~A}=8, \ldots$ and $0=$ not rated. Beta and the standard deviation of returns are calculated based on the returns for 1 year. Observations are winsorized at the $5 \%$ level to remove outliers.

* Indicates a significant difference from the pre-spin-off firm at the $1 \%$ level (two-tailed).

+ Indicates a significant difference from the post-spin-off parent at the $1 \%$ level (two-tailed).

considerably larger than subs following the spin-off, the latter being, on average, one-third the size of parents (and the previously combined firm) as measured by market values of equity and total sales. Notably, parents tend to liberalize their dividend policies relative to the previously combined firm, while subs tend to tighten them. Parents are also more profitable (higher return on equity) in the year following the spin-off, have higher stock ratings, and are expected to have lower earnings growth (higher earnings-to-price ratio $[E / P])$ in the future relative to subs. Parents also appear less risky than the sub (lower book-to-price ratio $[\mathrm{B} / \mathrm{P}]$ and lower standard deviation of returns). Generally, parents tend to look similar to the original combined firm, suggesting that there are few incentives for investors facing fixed fiduciary responsibilities or investment strategies to alter their holdings in parents. In contrast, subsidiaries are significantly smaller, are less profitable, are higher risk, and have higher expected earnings growth (lower E/P) than the original combined firms. These differences make subs relatively less attractive to in- 
stitutions facing strict prudence standards or following large-value strategies and more attractive to institutions following small-growth strategies.

\section{B. Classification of Institutional Investors Based on Preferences}

Institutions are classified based on fiduciary standards using the classification provided on the Spectrum database. Spectrum identifies five classes of institutions: bank trusts, insurance companies, investment companies, independent investment advisers, and "other," which includes internally managed public and private pension funds, colleges and universities, foundations, and other miscellaneous institutions (e.g., law firms acting as trustees). We use the bank trust and insurance companies categories as reported. We combine the investment companies and independent investment advisors into one category called "investment advisors" because the two Spectrum categories are very similar in their fiduciary standards. Finally, we drop any institution that is not clearly a pension, university, or foundation endowment to form the final group, pensions and endowments.

We classified institutional investors into groups based on investment styles using the factor-analysis and cluster-analysis program described in Bushee (1998). First, we used prior research and guides on institutional ownership to construct 15 variables that have been used to describe the investment preferences of institutional investors (see, e.g., Badrinath, Gay, and Kale 1989; Lev 1991; Carson Group 1995; Del Guercio 1996; Falkenstein 1996). These variables measure the portfolio weighted averages of firm-specific characteristics such as fundamental ratios (E/P, B/P, and dividend yield), risk measures, stock ratings, firm size and maturity proxies, growth measures, and past earnings performance (see table A1 for definitions). We compute these variables for an institution's portfolio at each calendar quarter but use the average values for each calendar year in the subsequent analyses to avoid the possibility that 1 unusual quarter results in a misclassification. Next, we use factor analysis to combine these average annual variables into a set of four factors that explain the common variance among the characteristics. Finally, we perform a $k$ means cluster analysis on the factor scores to obtain the final separation of institutions into groups (Hair et al. 1995). ${ }^{4}$

Panel A of table 2 presents the results of the factor analysis, which produced four common factors. The first factor (FSIZE) indicates preferences for firm size, maturity, and index membership. Institutions with higher FSIZE scores tend to hold large, mature firms listed on the S\&P 500. The second factor

4. The cluster analysis was performed on an institution-year basis. Thus, a given institution was allowed to change types over time. In fact, we find a trend to more small-growth strategies later in the sample period, consistent with the findings of Bennett, Sias, and Starks (2000). In order to avoid any mechanical associations, we did not allow an institution to change types over a sample firm's event period. In other words, if an institution shows up as holding a given firm in our sample at any point in the period preceding the spin-off (up to 4 quarters before the announcement date), the style for that institution is held constant for that particular sample firm throughout the entire event period. 
TABLE 2 Factor Analysis and Cluster Analysis of Institutional Investor Characteristics

\begin{tabular}{lrrrr}
\hline & A. Factor Analysis & \multicolumn{5}{c}{} \\
\hline & \multicolumn{5}{c}{ Factors } \\
\cline { 2 - 5 } Variable & \multicolumn{1}{c}{ FSIZE } & PGROW & \multicolumn{1}{c}{ VALUE } & \multicolumn{1}{c}{ FIDUC } \\
\hline WAMC & .991 & .093 & -.040 & .016 \\
WASP & .829 & -.012 & .311 & -.068 \\
WATIME & .816 & -.264 & -.167 & -.173 \\
WAPRC & .580 & -.014 & -.063 & .255 \\
WAEGR & .025 & .869 & .022 & .052 \\
WASGR & -.188 & .732 & .044 & .226 \\
WABTA & .031 & .699 & -.126 & -.199 \\
WASTD & -.453 & .551 & .058 & -.192 \\
WAEP & .045 & .184 & .948 & .098 \\
WADP & .056 & -.320 & .710 & -.099 \\
WABP & -.269 & -.187 & .703 & -.422 \\
WADUP & .086 & .077 & .007 & .658 \\
WARATE & .055 & -.316 & .404 & .609 \\
WAPED & .279 & .112 & .251 & .460 \\
WADE & .194 & .060 & .190 & -.710 \\
\hline
\end{tabular}

B. Clusters Based on Factor Scores

\begin{tabular}{lcrrrr}
\hline & & \multicolumn{4}{c}{ Mean Factor Scores } \\
\cline { 3 - 6 } Cluster & $N$ & \multicolumn{1}{c}{ FSIZE } & VALUE & \multicolumn{1}{c}{ PGROW } & \multicolumn{1}{c}{ FIDUC } \\
\hline SV & 2,756 & -.325 & .539 & -.365 & -.427 \\
SG & 4,652 & -.941 & -.614 & .756 & -.305 \\
LG & 3,326 & .586 & -.068 & -.093 & .487 \\
LV & 4,232 & .785 & .377 & -.520 & .231 \\
\hline
\end{tabular}

C. Interaction between Clusters and Type of Institution

\begin{tabular}{lcrrrr}
\hline & LG & LV & SG & SV & Total \\
\hline Banks & 663 & 1,626 & 156 & 435 & 2,880 \\
Insurance companies & 283 & 230 & 215 & 219 & 947 \\
$\begin{array}{l}\text { Investment advisors } \\
\begin{array}{l}\text { Pensions and } \\
\quad \text { endowments }\end{array}\end{array}$ & 1,438 & 1,167 & 2,789 & 1,337 & 6,731 \\
$\quad$ Total & 345 & 478 & 329 & 160 & 1,312 \\
\cline { 2 - 6 } & 2,729 & 3,501 & 3,489 & 2,151 & 11,870 \\
\hline
\end{tabular}

Note. - Panel A presents the results of the factor analysis used to classify institutional investors based on style preferences. Fifteen variables were constructed to describe the investment preferences of institutional investors. These variables are defined in table A1. A factor analysis was then performed to combine these variables into four factors: FSIZE indicates preferences for firm size, maturity, and index membership; PGROW separates institutions based on preferences for historical sales, earnings growth, and firm risk; VALUE distinguishes institutions following "value" or "income" (dividend) styles from those following "growth" styles; and FIDUC captures portfolio selection based on fiduciary incentives. Factors are estimated using principal factor analysis with an oblique promax rotation. Panel B presents the results of the cluster analysis performed on the factor scores to obtain the final separation of institutions into groups. SV = small-value funds, $\mathrm{SG}=$ small-growth funds, $\mathrm{LG}=$ large-growth funds, and LV $=$ large-value funds. Clusters are formed using $k$ means cluster analysis; $N$ represents the number of institution-years in each cluster. Panel $\mathrm{C}$ presents the number of institutions in each of the style and type groups. 
(PGROW) represents preferences for historical sales, earnings growth, and firm risk. Institutions with high PGROW scores prefer riskier firms with high historical growth. The third factor (VALUE) distinguishes institutions following "value" or "income" styles from those following "growth" styles. Institutions with high (low) VALUE scores prefer firms with high (low) book-tomarket, earnings-price, and dividend-yields ratios. The final factor (FIDUC) captures portfolio selection based on fiduciary incentives. Institutions with high FIDUC scores prefer firms with high stock ratings, steady earnings growth, lower leverage, and positive earnings, which are characteristics that tend to be preferred by institutions facing strict fiduciary standards (Badrinath et al. 1989; Del Guercio 1996).

Panel B of table 2 shows the results of the cluster analysis. The four-cluster solution yields groups of institutions differing based on preferences for combinations of firm size and expected growth. Small-growth institutions tend to hold small firms with high historical and expected growth. Small-value funds prefer smaller-cap firms (though not as small as the small-growth funds) that are high on the value dimension and low on the prior growth-risk dimension. Large-value investors prefer large firms, which are high on the value and fiduciary dimensions and low on the historical growth-risk dimension. Finally, large-growth funds hold large firms that have greater future growth potential than firms held by large-value funds, but not as high as firms held by smallgrowth funds. Firms held by large-growth institutions also tend to be high on the fiduciary dimension and in the middle of the prior growth-risk dimension. ${ }^{5}$

Panel $\mathrm{C}$ of table 2 presents the number of institutions in each of the classification groups. Investment advisors and banks are the most prevalent types of institution reported on the Spectrum database. The numbers of institutions in each of the style groups are fairly similar, with a slightly higher incidence of small-growth and large-value styles. Although banks tend to follow largevalue styles and investment advisors tend to adopt small-growth styles, panel $\mathrm{C}$ shows that there is a significant amount of heterogeneity across the two classification methods, indicating that one method is not a proxy for the other.

\section{Empirical Results}

\section{A. Changes in Institutional Holdings around Spin-Offs}

1. Results for spin-off parents. We present results for both levels and changes of institutional holdings for various quarters around the spin-off announcement date (A) and effective date (E; see fig. 1 for a time line of relevant event quarters). Figure 2 depicts the mean percentage of institutional holdings, defined as the ratio of institutional ownership to total ownership, for each quarter from $\mathrm{A}-5$ to $\mathrm{E}+4$. Holdings for the parent prior to quarter $\mathrm{E}$ represent

5. We compared our style classifications for the year 1995 to the self-reported style classifications documented in Carson Group (1995). For the 541 institutions we were able to match, we found that our classification scheme matched the self-reported style in over $88 \%$ of the cases. 


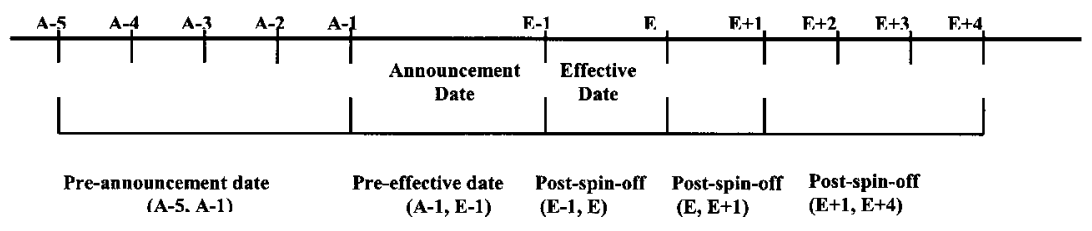

FIG. 1.-Time line of relevant spin-off dates. Each date indicated on the time line represents a calendar quarter end date relative to the announcement date or effective date of the spin-off. The date A represents the first calendar quarter end after the announcement date of the spin-off, and the date E represents the first calendar quarter end following the effective date of the spin-off. Calendar quarter end dates are used to correspond with the institutional holdings data, which are available only at calendar quarter ends. The announcement date is the date that the spin-off is first announced to the public. The effective date is the first date on which the parent and sub trade as separate entities and corresponds to the ex date for the majority of sample observations (in a small number of cases, trading in the sub is delayed up to 15 days). Both dates are obtained from the SDC database and cross-checked on Lexis-Nexis and the Wall Street Journal Index. The mean (median) number of trading days from A -1 to the announcement date is 31.4 (30.5). The mean (median) number of trading days from the effective date to $\mathrm{E}$ is 18.9 (33.0).

institutional holdings for the combined firm prior to the effective date of the spin-off. The figure indicates a significant (at the $1 \%$ level) mean increase in institutional ownership in the 4 quarters leading up to the announcement $(\mathrm{A}-5$ to $\mathrm{A}-1){ }^{6}$ Thus, there is no evidence that institutions anticipate the spin-off and reduce their holdings to avoid having to rebalance after the spinoff is announced.

Table 3 presents mean changes in the percentage of institutional ownership over key horizons around the spin-off transaction. These changes are adjusted for the average change in institutional holdings across all firms on the Spectrum database over the same period to adjust for time trends in institutional ownership. Panel A indicates that there is no evidence of immediate changes in overall institutional holdings of the combined firm between the spin-off announcement and effective dates ( $\mathrm{A}-1$ to $\mathrm{E}-1)$. This result is consistent with the conclusions reached by Vijh (1994), who finds no significant price changes in the period between the announcement and effective date. He conjectures that this result stems from buyer uncertainty about the individual values of the parent and sub, which deters trading between the announcement date and effective date. However, panel B shows that, despite these incentives, banks, the institutions facing the most restrictive fiduciary standards, significantly reduce their mean holdings in the combined firm immediately following

6. One explanation for this increase could be the fact that firms that engage in spin-offs tend to be high-growth firms (Krishnaswami and Subramaniam 1999) and that institutional investors are increasing the ownership in the firms as they become larger over this period. Such changes would not necessarily be captured by the average adjustment for changes in holdings described below. 


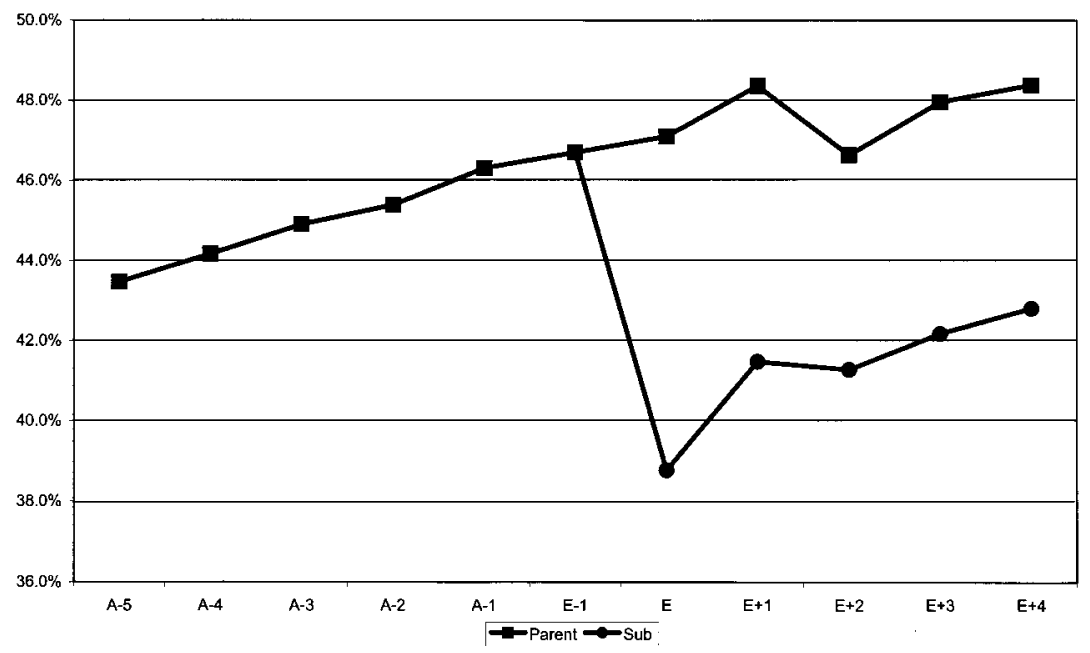

FIG. 2.-Percentage of institutional holdings in spin-off parents and subs by quarter, relative to spin-off announcement date (A) and effective date (E).

the announcement of the spin-off. Panel B shows that no other institutional type or style reduces its holdings during this period, and differences between changes in holdings for banks and other institutional types are significant below the $5 \%$ level. $^{7}$

The results for change in parent holdings subsequent to the spin-off (E - 1 to E), table 3 show little evidence of significant changes in institutional holdings. This evidence is consistent with the fact that parents are very similar in key firm characteristics to the combined firm. Panel B shows a small but significant increase in the holdings of parents by institutions following smallgrowth styles. These results suggest that the only institutional investor clientele we have defined that could be associated with observed price pressure documented by Vijh (1994) are institutions following small-growth strategies.

2. Results for spin-off subsidiaries. Figure 2 and table 3 indicate that there is a substantial decline in institutional holdings in the subsidiaries evident in the quarter (E - 1 to $E$ ) in which trading in the sub begins. Panel A of table 3 reports that the mean-adjusted decline of $-7.97 \%$ in institutional holdings in subs, from a mean level of $46 \%$ in the quarter prior to the effective

7. To test whether the magnitude of a mean change in holdings by one group of institutions is significantly different from mean holdings by other groups, we perform ANOVA tests. These results are not reported in tables but will be referred to where relevant. Also, we examined median changes in holdings and the percentage of positive changes in holdings and found results consistent with the mean changes reported in table 3 . 
TABLE 3 Adjusted Mean Changes in Institutional Holdings over Spin-Off Horizons by Institutional Styles and Types

A. Total Institutional Ownership

\begin{tabular}{|c|c|c|c|c|c|c|c|c|}
\hline $\begin{array}{l}\text { Percent holdings at } E-1 \\
\text { Change in holdings }(A-1, E-1) \\
\text { Parent change in holdings }(E-1 \mathrm{E}) \\
\text { Parent change in holdings }(E, E+1) \\
\text { Sub change in holdings }(E-1, E) \\
\text { Sub change in holdings }(E, E+1)\end{array}$ & $\begin{array}{r}46.28 \\
.21 \\
.40 \\
.98 \\
-7.97 * * \\
2.41 * *\end{array}$ & & & & & & & \\
\hline \multicolumn{9}{|c|}{ B. Ownership by Group of Institution } \\
\hline & \multicolumn{4}{|c|}{ Institutional Types } & \multicolumn{4}{|c|}{ Institutional Styles } \\
\hline Percent holdings at $\mathrm{E}-1$ & 10.63 & 26.81 & 4.27 & 4.57 & 10.28 & 13.47 & 11.58 & 6.29 \\
\hline Change in holdings $(\mathrm{A}-1, \mathrm{E}-1)$ & $-.77 *$ & .68 & .15 & .17 & -.05 & -.32 & .27 & .20 \\
\hline Parent change in holdings $(\mathrm{E}-1, \mathrm{E})$ & -.20 & .74 & -.04 & -.12 & .04 & -.06 & $.71^{*}$ & .01 \\
\hline Parent change in holdings $(E, E+1)$ & .20 & .68 & .00 & .11 & -.04 & .36 & .09 & .05 \\
\hline Sub change in holdings $(E-1, E)$ & $-3.42 * *$ & $-2.50 * *$ & $-.78 * *$ & $-1.29 * *$ & $-1.13^{*}$ & $-4.40 * *$ & .35 & -.66 \\
\hline Sub change in holdings $(\mathrm{E}, \mathrm{E}+1)$ & .21 & $2.06 * *$ & .07 & .08 & .09 & -.36 & $2.03 * *$ & .00 \\
\hline
\end{tabular}




\section{Ownership by Investment Style Groups among Banks and Investment Advisers}

\begin{tabular}{|c|c|c|c|c|c|c|c|c|}
\hline & \multicolumn{4}{|c|}{ Banks } & \multicolumn{4}{|c|}{ Investment Advisors } \\
\hline & $\begin{array}{c}\text { Large-Growth } \\
(\%)\end{array}$ & $\begin{array}{c}\text { Large-Value } \\
(\%)\end{array}$ & $\begin{array}{c}\text { Small-Growth } \\
(\%)\end{array}$ & $\begin{array}{c}\text { Small-Value } \\
(\%)\end{array}$ & $\begin{array}{c}\text { Large-Growth } \\
(\%)\end{array}$ & $\begin{array}{c}\text { Large-Value } \\
(\%)\end{array}$ & $\begin{array}{c}\text { Small-Growth } \\
(\%)\end{array}$ & $\begin{array}{c}\text { Small-Value } \\
(\%)\end{array}$ \\
\hline Percent holdings at $\mathrm{E}-1$ & 2.60 & 7.06 & .13 & .52 & 5.06 & 4.67 & 10.39 & 4.81 \\
\hline Change in holdings $(\mathrm{A}-1, \mathrm{E}-1)$ & $-.38 *$ & -.40 & -.02 & .02 & .31 & .03 & .35 & .10 \\
\hline Parent change in holdings $(\mathrm{E}-1, \mathrm{E})$ & .06 & -.07 & .03 & $-.13 *$ & -.04 & -.27 & .57 & .18 \\
\hline Parent change in holdings $(\mathrm{E}, \mathrm{E}+1)$ & -.08 & .10 & .00 & .12 & .17 & $.41 * *$ & -.01 & -.10 \\
\hline Sub change in holdings $(E-1, E)$ & -.41 & $-2.35^{* *}$ & -.04 & $-.30 * *$ & -.15 & $-1.61 * *$ & .39 & -.31 \\
\hline Sub change in holdings $(\mathrm{E}, \mathrm{E}+1)$ & -.01 & -.03 & .04 & .09 & .02 & -.19 & $1.71 * *$ & -.08 \\
\hline
\end{tabular}

NotE. - Sub $=$ subsidiary. Changes in holdings are adjusted for the average change in holdings by institutions of the same type over the same period of time. A indicates the quarter in which the announcement date falls, and E indicates the quarter in which the effective date falls. See fig. 1 for a time line. Panel A provides the overall change in holdings. Panel B presents

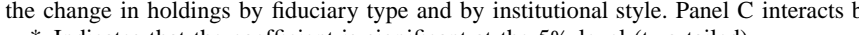

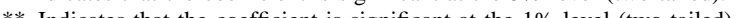


date, is highly significant. ${ }^{8}$ The panel also shows a significant rebound in institutional holdings of subs in the quarter subsequent to the spin-off.

The changes in holdings by type of institutions are documented in table 3 , panel B. Banks continue to sell their interests in subs in the quarter containing the effective date of the spin-off, generating the largest decline $(-3.42 \%)$ among the institutional types. We also observe a significant mean decline of $-1.29 \%$ in pension and endowment holdings. Furthermore, the decrease in sub holdings by banks, pensions, and endowments is permanent, as there is no indication that institutions held to the highest fiduciary standards come back to these securities in quarters subsequent to $E+1$ (not reported). These findings indicate that banks and pensions have strong incentives to realign their portfolios quickly for fiduciary reasons even though transactions costs could be avoided by delaying trading until scheduled portfolio rebalancing dates.

We also observe a significant mean decline of $-2.5 \%$ in investment advisor holdings and a significant mean decline of $-0.78 \%$ in insurance company holdings of subs that are difficult to attribute to fiduciary restrictions. Our subsequent classification of institutions by strategic investment style reconciles these results.

Table 3, panel B, presents results for the decomposition by investment style. The panel reports a significant decrease in large-value investor holdings of subsidiaries of $-4.4 \%$, nearly 4 times as large as the next largest decline in holdings observed for large-growth institutions. Differences between the decline in large-value and all other strategies are significant at the $1 \%$ level. Large-growth institutions also significantly reduce their holdings in the sub, consistent with the subs being smaller firms. Not surprisingly, small-growth institutions do not reduce their holdings in the subs. In fact, institutions following small-growth styles are the only ones to increase their holdings in subs significantly in the quarter after the spin-off. Tests of differences across styles confirm that small-growth trading behavior is statistically different from all other style groups. ${ }^{9}$

8. As mentioned earlier, institutions have to report holdings of a given firm only if the holdings are greater than 10,000 shares or $\$ 200,000$ in market value. Consequently, a reported decrease in subsidiary holdings could just be a mechanical result if, because of the spin-off, the institutions dropped below the mandatory reporting requirements for their subsidiary holdings even though they did not actually reduce their percentage holdings. In order to ensure that this possibility was not affecting our results, we replaced all zero holdings in the subsidiaries by institutions that had reported holdings in the firm before the spin-off with the lower of 10,000 shares or $\$ 200,000$ of market value. Results did not change when we performed this analysis.

9. Form $13 \mathrm{~F}$ data aggregates across all funds of the reporting institution. For example, all Fidelity funds are aggregated into one total holdings amount. This aggregation potentially creates noise in our style classifications because the analysis using the $13 \mathrm{~F}$ Spectrum data will only pick up the one predominant style. In an attempt to ensure that this data issue does not affect our results, we ran the change in holdings test using the Spectrum Mutual Fund database. This database breaks mutual fund holdings into individual funds. We do not use this database for the primary analysis because mutual fund holdings are only a small subset of total institutional holdings and are primarily concentrated in the investment advisor category. Because the $13 \mathrm{~F}$ Spectrum data and the Mutual Fund data cannot be merged, we cannot use the Mutual Fund 
Next, we interact style and type classifications to assess the overlap between investment style choices and the strength of fiduciary standards. These results are summarized in table 3, panel C. The panel shows that banks decrease their holdings in the subs regardless of their strategic proclivity. Also, the first row of the panel shows that few banks tend to follow small-cap strategies in the first place (mean holdings by such banks are below 1\%). Both of these findings indicate that fiduciary concerns are the main driver of bank investment behavior and inhibit even the small number of banks that follow small-growth strategies from increasing their holdings in small subs.

The decomposition of investment advisors by strategy in table 3, panel C, confirms that large-value strategies primarily drive the overall decline by investment advisors reported earlier; small-growth investment advisors actually increase (though insignificantly) their holdings in subs. Interactions between investment styles and pensions and insurance companies (not reported) indicate that pensions' behavior is similar to banks while insurance companies' behavior is similar to investment advisers, which is consistent with the differences in fiduciary concerns faced by these two types of institutions. This evidence indicates that where fiduciary standards are less restrictive, as in the case of investment advisors, investment styles are the primary driver of trading behavior.

In addition to showing the interaction between investment style and fiduciary classifications, the results in panel $\mathrm{C}$ provide strong additional support for the prediction that corporate spin-offs lead to preference-induced trading based on fiduciary standards considerations. An institution that is most concerned with fiduciary restrictions will invest in large, mature firms with stable earnings and lower risk. Based on our style classifications, this implies, for example, that the banks that are most concerned with fiduciary restrictions will follow a large-value style. As can be seen in panel $\mathrm{C}$, while all banks decreased their holdings in the sub, the greatest decrease $(-2.35 \%)$ was by banks with the greatest fiduciary constraints. Pensions demonstrate the same pattern as banks. Pensions that follow an investment style indicative of the most extreme fiduciary constraints (large-value) show a significant $-0.82 \%$ decline in the sub in the quarter subsequent to the spin-off, whereas pensions less restricted by fiduciary constraints do not significantly reduce their holdings in the subs (not reported).

As an additional test of the strength of our preference-induced trading predictions, we partition the investment style classifications based on the firm size and value-growth factor scores (see table 2) to focus on institutions that adhere most closely to their implicit style (not reported). In the case of largevalue institutions, the institutions that most closely follow a large-value strategy decrease their holdings by $-3.33 \%$, whereas the other large-value insti-

data for testing fiduciary standards. Also, these data are not required by the Security and Exchange Comission and thus are not available every quarter for most funds and are possibly subject to voluntary reporting biases. Nevertheless, investment style results using the Mutual Fund database are qualitatively similar to our main findings. 
tutions only decrease their holdings by $-1.43 \%$. Likewise, the small-growth institutions that most closely follow their style increase their holdings in the sub by $1.27 \%$, whereas all others only increase their holdings by $1.09 \%$. As a final check, we examine whether institutions that rebalance their portfolios around a spin-off make trades in the opposite direction in the subsequent quarter. We compute the percentage of individual institutions that sell the sub in the quarter of the spin-off and buy it back in the following quarter. This percentage is only $8 \%$ overall and ranges from $7 \%$ to $11 \%$ when computed by style and type. This finding suggests that, on average, the results for changes in holdings represent permanent, preference-induced rebalancing by each of the individual institutional owners in the sub.

Overall, the results for changes in institutional holdings in subsidiaries strongly support the prediction that fiduciary standards and investment-style considerations drive institutional trading behavior around spin-offs. The large declines in holdings by banks and by institutions following large-value strategies indicate the potential that the trading of these institutions drives the observed downward price movements in subs during the first 30 days after the spin-off (Brown and Brooke 1993). Also, the significant increase in sub holdings by institutions following small-growth strategies would be consistent with the observed rebound in sub prices in the period 30-60 days after the spin-off (Brown and Brooke 1993). The next section directly tests whether these changes in holdings are associated with the price movements in parents and subs after spin-offs.

\section{B. Changes in Institutional Holdings and Stock Returns after Spin-Offs}

1. Results for spin-off parents. Table 4, panel A, presents the results of regressions of size-adjusted returns over three cumulation periods after the spin-off on changes in institutional holdings in parents. Size-adjusted cumulative abnormal returns (CARs) are calculated as buy-and-hold raw returns (compounded daily) less buy-and-hold returns to the firm's size decile over various periods identified in the tables and text. ${ }^{10}$ Mean CARs for parent firms over the different cumulation periods are presented in panel A, column 1. Day 0 returns represent ex date returns for the combined parent and sub. Because opening prices are not available for spun-off entities, we compute the implied effective date return for the combined entity by combining $e x$ date prices of the parent and sub in spin-off proportions and dividing by the last cum-date price of the combined firm (Vijh 1994). ${ }^{11}$ There is a significant

10. All returns tests were performed using market-adjusted and market model abnormal returns as well. No significant differences in our results were observed.

11. Because of some errors in CRSP's calculation of spin-off dividends, we combined postspin-off prices using spin-off dividends obtained from Lexis-Nexis Academic Universe and $C C H$ Capital Changes Reports. Also, all prices were hand checked using the S\&P Daily Stock Price Record. In a small number of cases in our sample (19) where sub trading is delayed, we discounted the sub price back to the ex date using the market return. For these observations, the day +1 refers to the first day in which trading occurs. 


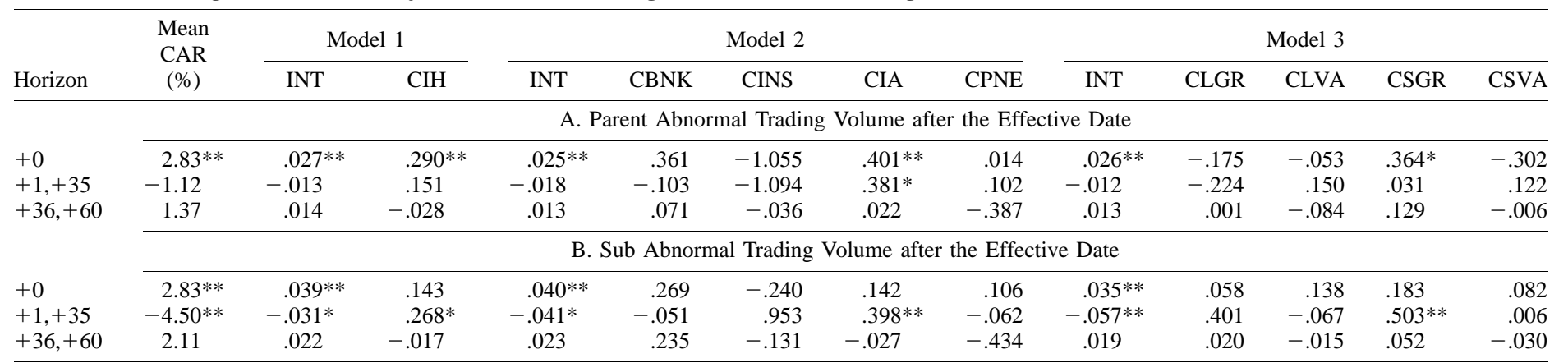

NoTE. - Sub = subsidiary; CAR = cumulative abnormal returns. Size-adjusted abnormal returns are calculated as buy-and-hold raw returns less the corresponding buy-and-hold size portfolio return. All regressors are changes in the level of holdings by institutions or groups of institutions over the quarter surrounding the spin-off ( $E-1$, E) for day 0 regressions and over the 2 quarters surrounding the spin-off $(\mathrm{E}-1, \mathrm{E}+1)$ for other horizons. Definitions of the regressors are as follows. $\mathrm{ClH}=$ change in total institutional holdings, $\mathrm{CBNK}=\mathrm{chang}$ in bank holdings, $\mathrm{CINS}=$ change in insurance company holdings, CIA $=$ change in investment advisor holdings, $\mathrm{CPNE}=$ change in pension and endowment holdings, CSVA $=$ change in small-value institution holdings, CSGR = change in small-growth institution holdings, CLGR = change in large-growth institution holdings, and CLVA $=$ change in large-value institution holdings; INT indicates the intercept in the regression. Day 0 is the effective date of the spin-off. The day 0 return represents the implied effective date return for the combined entity, which is obtained by combining ex date prices of the parent and sub in spin-off proportions and dividing by the last cum-date price of the combined firm. The other horizons represent returns fo the parent or sub only.

* Indicates that the coefficient is significant at the 5\% level (two-tailed)

** Indicates that the coefficient is significant at the $1 \%$ level (two-tailed). 
$2.83 \%$ abnormal return on the effective date of the spin-off that is comparable in magnitude with the return reported by Vijh (1994) in an earlier sample period. Abnormal returns for the horizons +1 through +35 and +36 through +60 represent returns in the post-spin-off parent only. There are no significant abnormal returns over these cumulation periods, indicating that any price movement in the parent attributable to institutional trading, if it does exist, is likely to be concentrated on the effective date of the spin-off.

In model 1, we regress abnormal returns on the total change in institutional holdings $(\mathrm{CIH})$, whereas models 2 and 3 replace $\mathrm{CIH}$ with the changes in holdings of institutions classified by fiduciary standards and investment styles, respectively. For day 0 regressions, changes in holdings are measured from the end of quarter $E-1$ to the end of quarter $E$. For other horizons, changes are measured from $\mathrm{E}-1$ to $\mathrm{E}+1$ because the longer-horizon return periods often span 2 calendar quarters. The results of panel A, model 1, report a significant association between changes in institutional holdings in the parent and the significant abnormal return observed on the effective date (day 0 ).

Results from models 2 and 3 indicate that the association between $\mathrm{CIH}$ and CAR is driven by investment advisors and by institutions following smallgrowth investment styles. Recall that small-growth institutions were the only type of institution to increase holdings significantly in the parent immediately after the spin-off. These results are consistent with Vijh's (1994) conjecture that abnormal returns immediately following a spin-off reflect a willingness on the part of specific clienteles to pay a premium for stocks with certain attributes. In this case, the evidence suggests that small-growth investment advisors, lacking adequate substitutes, pay a premium for established small parents when they emerge from spin-offs. ${ }^{12}$

While the association between preference-induced changes in holdings and returns just noted are statistically significant, they are small in economic magnitude (e.g., the coefficient of 0.364 on change in small-growth institution holdings in model 3 indicates that a $1 \%$ marginal increase in holdings by small-growth institutions would only result in a $0.36 \%$ increase in abnormal returns). Thus, institutional investor clienteles, as we have defined them, appear only to explain a small portion of the price pressure identified by Vijh (1994), indicating that apparent price pressure is associated with (1) more refined classifications of style and fiduciary clienteles than we offer, (2) preference-induced trading for reasons other than those we in-

12. This association is also consistent with window dressing by investment advisers and institutions following small-growth strategies. It is not clear, however, why we do not find evidence that other institutional types engage in the same activity. The general lack of evidence of this phenomenon in our data is consistent with the conclusions of Lakonishok et al. (1991) that window dressing is not prevalent. In any event, if our evidence does reflect window dressing, it is clear that it must occur immediately after the run-up in the price occurs on the effective date. The significant association between change in investment advisor holdings and abnormal returns over days $+1,+35$ is consistent with window-dressing behavior, but the lack of significant mean abnormal returns indicates that institutional trading even for the purposes of window dressing is not associated with price pressure. 
vestigate in this article, and (3) another phenomenon different from any conjectured previously.

2. Results for spin-off subsidiaries. Table 4, panel B, presents return regressions for subsidiaries. The first row of this panel indicates that there is no evidence that institutional trading in the sub accounts for the large combined day 0 return. The next two rows present results for return horizons +1 through +35 and +36 through +60 , which reflect returns for only the sub. The mean abnormal return for subs is a significantly negative, $-4.50 \%$ from days +1 to +35 , which is almost identical to the decline reported by Brown and Brooke (1993). Results from model 1 provide a starting point for interpreting abnormal returns to subs following the spin-off. The results show a significant association between the overall change in holdings, $\mathrm{CIH}$, and abnormal returns from days +1 to +35 . The significant coefficient of 0.268 on quarterly changes in holdings in model 1 translates to a return of $-1.5 \%$ using the average value of $\mathrm{CIH}(-5.5 \%)$ for the horizon $\mathrm{E}-1, \mathrm{E}+1$. This estimate indicates that quarterly changes in institutional holdings account for $33 \%$ of the abnormal return in subs after the spin-off.

Analysis of models 2 and 3 sheds more light on whether preference-induced trading by institutions is associated with apparent price pressure. Model 2 and 3 results show that there are no significant relations between the negative abnormal returns in subs and the preference-induced trading of banks, pensions, and large-value and large-growth institutions. Instead, only changes in investment advisor holdings and small-growth institution holdings are associated with abnormal returns. Combined with the results in table 3 , these results likely indicate that these groups of institutions are trading in subs for informational reasons (such as return performance or earnings news releases) rather than noninformational reasons associated with institutional preferences. ${ }^{13}$

Overall, the results in table 4 appear to contradict Brown and Brooke's assertion that "institutional investors' need to liquidate shares in new spinoff companies creates temporary but substantial selling pressure, which significantly affects the value of securities" (1993, p. 54). There is also no evidence that the subsequent price reversals in subs on days +36 through +60 are associated with preference-induced trading or with institutional trading in general. This delayed positive price response may be attributable to the arrival of new information about subs or, alternatively, contrarian trading or initial mispricing. Thus, the causes of the initial price decline and eventual rebound observed for subs remain unidentified.

13. We also computed these regressions for both the parents and subs including size and liquidity as controls. Size was measured as the $\log$ of market value equity, and liquidity was measured as the abnormal weekly turnover from days +60 to +120 . The results are qualitatively unchanged. 


\section{Sensitivity Analyses}

\section{A. Institutional Investors and Abnormal Trading Volume}

Because our data does not permit exact matching between institutional holdings and return intervals, a potential criticism is that, because of this measurement error, our tests lack the power to find an association between institutional trading and short-window returns using quarterly changes in institutional holdings. To demonstrate further the adequate power of our research design, we first document the presence of abnormal trading volume in parents and subs on days that abnormal returns are also observed. ${ }^{14}$ Then we show that this abnormal trading volume is associated in the expected direction with the quarterly changes in institutional holdings documented in table 3 , indicating that our tests do have power to detect an association between institutional trading and abnormal market activity related to spin-offs when it occurs.

Table 5 reports the results from regressions of changes in institutional holdings on abnormal trading volumes subsequent to the spin-off. We compute abnormal trading volume as the firm's trading volume (defined as dollar value of volume divided by the dollar value of shares outstanding) less the market trading volume (defined similarly). Because volume data are available for parents and subs separately on the effective date, the day 0 volumes represent only volume in the parent or sub, respectively. ${ }^{15} \mathrm{We}$ also include controls in these regressions (not reported) for size, S\&P 500 inclusion, and level of institutional ownership (Tkac 1999).

Table 5, panel A, presents the results for parents. The results indicate that spin-off parents, on average, experience abnormal trading volume on the effective date of the spin-off and that the change in total institutional holdings is significantly positively associated with the abnormal volume. This relation is mainly driven by investment advisers and small-growth institutions and indicates that the observed quarterly increases in holdings by these institutions (see table 3) are associated with the abnormal volume in the parents on the effective date of the spin-off. This result supports the conclusion in Section III.B.1 that buying by these two groups of institutions contributes to price pressure in the parent after the spin-off.

Panel B of table 5 presents the results of regressing abnormal trading volume on change in holdings in the subsidiary stocks. The mean abnormal turnover in subs is significantly positive on the effective date and remains significantly positive throughout the next 60 days. The results of model 1 reveal a strong negative relation between changes in institutional holdings and abnormal volume over all of the cumulation horizons. These results indicate that institu-

14. Shleifer (1986) demonstrates a significant relation between abnormal returns and abnormal volume in arguing that index buying immediately after S\&P 500 listing accounts for the anomalous return.

15. We also compute abnormal trading volume as the firm's trading volume (defined as volume divided by shares outstanding) less the average trading volume of the firm's size decile. No significant differences in results were observed. 
TABLE 5 Regressions of Abnormal Trading Volume on Changes in Institutional Holdings

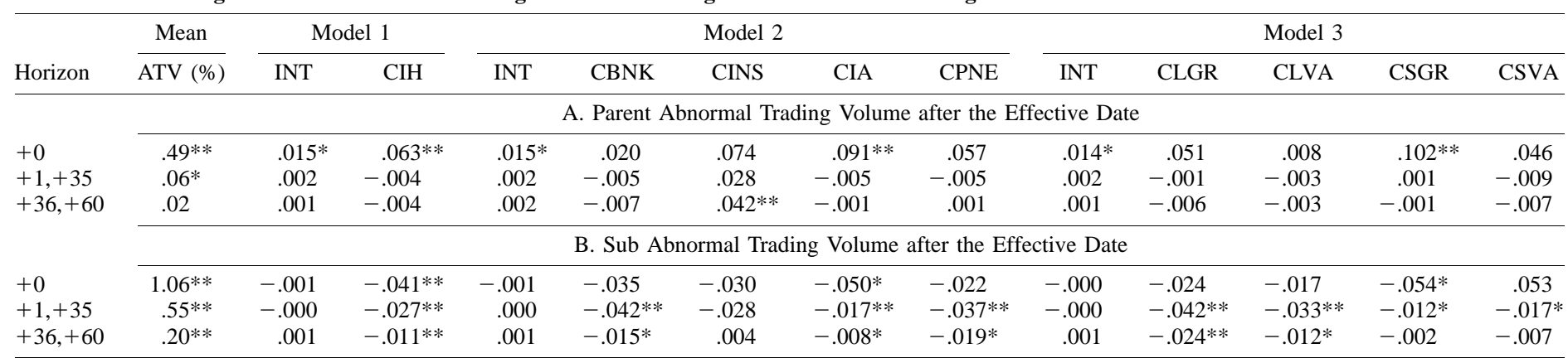

NotE. - Sub $=$ subsidiary. Average daily abnormal trading volume is calculated as the daily average of volume divided by shares outstanding less the market portfolio volume divided by shares outstanding. All regressors are changes in the level of holdings by institutions or groups of institutions over the quarter surrounding the spin-off ( $E-1$, E) for day 0 regression and over the 2 quarters surrounding the spin-off $(\mathrm{E}-\mathrm{I}, \mathrm{E}+\mathrm{I})$ for other horizons. The regressors are as defined in the note to table 4; INT indicates the intercept in the regression. Day 0 is the effective date of the spin-off. Because volume data are separately available for parents and subs on the effective date, the day 0 volume, as well as the other horizons, represent abnormal volume in the parent or sub only.

* Indicates that the coefficient is significant at the $5 \%$ level (two-tailed)

** Indicates that the coefficient is significant at $5 \% 1 \%$ level (two-tailed). 
tional selling of sub stocks in table 3 is associated with a higher-than-expected trading volume in the subs. Model 2 reveals that the only type of institution whose trading is not associated with the institutional investor effects observed for model 1 are insurance companies, consistent with the change-in-holdings results displayed in table 3 . Model 3 provides evidence that selling by largegrowth and large-value institutions is associated with significantly higher abnormal volume, which is again consistent with results in table 3 .

The trading volume analyses reported above increase our confidence that the returns tests have sufficient power to discover price pressure in subs driven by institutional preferences, if it exists. The significant associations between abnormal trading volume and changes in holdings are completely consistent with predicted and observed changes in the holdings of institutions based on their preferences. Our results strongly suggest that there is substantial and immediate trading volume around spin-offs attributable to investor preferences but that this particular volume is not the source of the observed abnormal returns.

\section{B. Tests for Measurement Error}

In addition to the analysis of abnormal volume, we perform several other analyses to demonstrate the adequacy of our research design to find price pressures, if they exist. First, we perform reverse regressions. While random measurement error in an independent variable creates coefficient bias, random error in the dependent variable does not cause a violation of the regression assumptions. Consequently, we regress $\mathrm{CIH}$ on size-adjusted returns. We also regress the change in holdings for each style and type of institution separately on size-adjusted returns. In all cases, the results are qualitatively identical to those reported in table 4 (not reported). This provides strong evidence that measurement error in $\mathrm{CIH}$ is not creating a downward bias in the coefficients, thus leading to incorrect inferences.

Next, to ensure that the length of the change-in-holdings period does not induce measurement error, we estimate regressions using the change in holdings through quarter $E$, instead of quarter $E+1$. We also segment the sample based on the horizon between the effective date and the end of the calendar quarter and use the change-in-holdings variable that most precisely corresponds to the various return intervals in each regression. We observe no qualitative changes in the results from either of these approaches.

\section{Results including When-Issued Shares}

Many spin-off transactions trade on a "when-issued" basis prior to the effective date whereby an investor can buy or sell when-issued shares in the parent or sub that settle into regular shares after the spin-off becomes effective. It seems reasonable that if institutional investors want to rebalance their holdings in the new parent or sub, they would do so in the when-issued period. Thus, excluding the when-issued period could explain the lack of price pressure results in the sub. We collected data for the 50 parents and 108 subs in our 
sample that traded on a when-issued basis before the effective date. The parents traded on a when-issued basis for 12 days on average, and the subs traded on a when-issued basis for an average of 13 days. During this period, the average abnormal trading volume for both the parents and subs is negative. In fact, every firm (both parent and sub) experienced negative abnormal trading volume in this period. These results provide evidence that there is very little trading taking place in this period, indicating that institutions wait until the effective date to trade. Nonetheless, we ran all of the returns analyses described in Section III.B using the first day of the when-issued period as the effective date where relevant. Consequently, if a given parent or sub traded on a whenissued basis, then the day 0 return is the abnormal return to that when-issued security on the first day it began trading on a when-issued basis. Otherwise, the day 0 return is the abnormal return on the effective date. Inferences from these analyses (not reported) are qualitatively similar to the analyses that ignored the when-issued period.

\section{Results Conditioned on Prior Level of Holdings and Characteristics of Spun-Off Firms}

Next, we examined the possibility that preference-induced price pressure in parents and subs only exists in spin-off transactions where the spun-off entities have characteristics that are very different from the combined entity or the institution must buy or sell large blocks to establish its new desired holdings level. For example, it is likely that price pressure would be most pronounced in subs when banks and large-value institutions had large holdings in the combined firm (necessitating a large liquidation of shares) and when the sub is a small firm with a relatively illiquid market for its shares. We use institutional ownership in the pre-spin-off firm to examine the case in which institutions may need to buy or sell large blocks of shares to establish its new desired holdings level. We use market value of equity to examine the case in which the spun-off entities have characteristics very different from the combined entity. We form partitions by splitting the sample at the median of the institutional ownership in the pre-spin-off firm and at the median of market value of equity of the post-spin-off entity to create four groups of spin-off firms: low prior ownership and large post-spin-off entity (LPLG), high prior ownership and large post-spin-off entity (HPLG), low prior ownership and small post-spin-off entity (LPSM) and high prior ownership and small postspin-off entity (HPSM). ${ }^{16}$

16. We look at an absolute measure of size, rather than the relative size of the parent or sub compared with the combined entity, because institutions often use minimum (or maximum) size benchmarks to guide their holdings decisions (O'Barr and Conley 1992). As a check, we ran the analysis using relative size measures and found results that were similar, but smaller in magnitude. We also performed this analysis using dividend yield, earnings-price ratio, and twodigit SIC comparisons instead of size. Results from this analysis were again qualitatively similar, though smaller in magnitude, to an analysis based on size. Thus, firm size seems to be the most important driver of institutional rebalancing and price pressure. 
Table 6 presents results of this analysis for the two extreme style classifications: large value and small growth. ${ }^{17}$ The table reports both adjusted changes in holdings in the quarter of the spin-off and the results of a regression of size-adjusted returns on changes in holdings interacted with indicator variables for the type of firm. Panel A reports results for spin-off parents. Although table 3 revealed no significant changes in ownership by large-value institutions in the parent, table 6 shows that large-value institutions significantly increase their ownership during the spin-off quarter when the parent is relatively large and this type of institution had low prior ownership. However, as shown in the table, these holdings changes have no effect on returns on or after the effective date.

Panel A also shows that small-growth institutions significantly increase holdings in the post-spin-off parent in the spin-off quarter when they had low prior ownership regardless of the size of the parent, implying that spin-offs yield parents that do not exceed maximum size benchmarks of such institutions. In the case of small parents, the increase in holdings of small-growth institutions with low prior ownership is significantly associated with the return on the effective date, as well as abnormal volume (not reported), suggesting preference-induced price movements. Multiplying the total effect implied by the coefficient (0.409) times the average holdings change in this partition $(1.78 \%)$ yields a marginal effect of $0.7 \%$, which is one-quarter of the mean effective date return reported in table 4 . This result provides some limited support for Vijh's (1994) conjecture that clientele effects drive part of the effective date abnormal returns.

Table 6, panel B, reports results of the partition analyses for subs. Largevalue institutions significantly reduce their holdings in all cases except where they had low prior ownership and the sub is large. Despite the large decreases in holdings by large-value institutions with high prior ownership (the HPLG and HPSM partitions), there is no evidence that these large liquidations result in price movements. However, the significant reduction in holdings of largevalue institutions in small subs with low prior ownership (the LPSM partition) does result in significant price movements during the +1 through +35 horizon, when most of the reduction in sub prices occurs. In fact, multiplying the total coefficient for the LPSM group multiplied by the average holdings change implies a 3.2\% marginal impact on returns for these firms. This change in holdings is also marginally significantly associated with abnormal volume during this period (not reported).

Thus, there is some evidence that selling by large-value institutions after the spin-off is associated with price movement in the subs. However, the magnitude of the effect is not sufficient to explain fully the negative returns found in Brown and Brooke (1993), and the evidence of preference-induced price pressure is not found in the partitions (HPSM, HPLG) where it would be mostly likely to

17. Results for total institutional ownership and banks are similar to those for large-value institutions. 


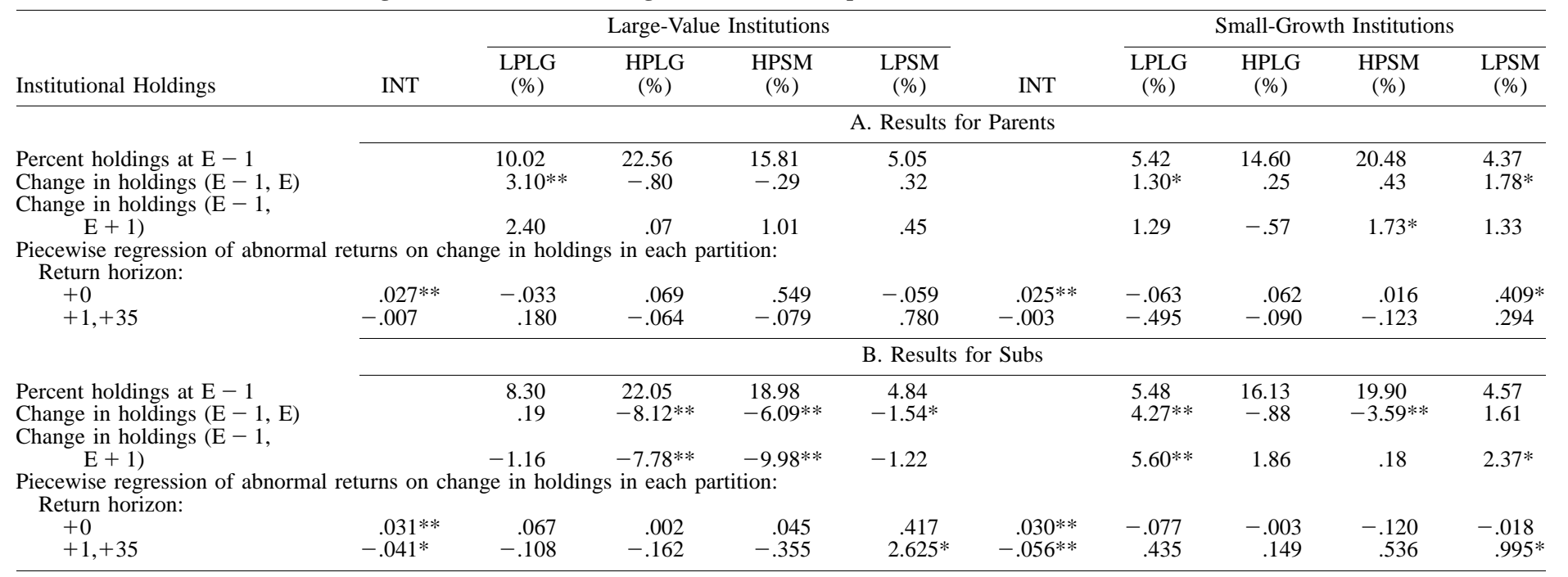

NoTE. - Sub $=$ subsidiary. This table presents changes in holdings by large-value and small-growth institutions in the quarter surrounding spin-off transactions and results of regressing size-adjusted returns on change in holdings variables over post-spin-off date horizons conditioned on the prior level of holdings in the combined entity and the post-spin-off size of the paren (market value) into Larg (LG) and Small (SM) substes. The size partition was performed separtely for post-spin-off parents and subs. Changes in holdings are adjusted for the average change in holdings by institutions of the same type over the same period of time. Size-adjusted abnormal returns are calculated as buy-and-hold raw returns less the corresponding buy-andhold size portfolio return. All regressors are changes in holdings by institutions over the quarter surrounding the spin-off $(\mathrm{E}-1, \mathrm{E})$ for day 0 regressions and over the 2 quarters surrounding the spin-off $(E-11, E+1)$ for day +1 through +35 . INT indicates the intercent in the regression. Day 0 is the effective date of the spin-off The day 0 return represents the implied effective date return for the combined entity, which is obtained by combining ex date prices of the parent and sub in spin-off proportions and dividing by the last cum-date price of the combined firm. The day +1 through +35 returns represent returns for the parent or sub only.

* Indicates that the change in holdings or coefficient is significant at the $5 \%$ level (two-tailed).

** Indicates that the change in holdings or coefficient is significant at the $1 \%$ level (two-tailed). 
occur given the magnitude of institutional holdings changes. One likely explanation for why price pressure occurs in the LPSM partitions but not in the other partitions is that LPSM firms are, on average, $40 \%$ of the size of HPSM firms (not reported). Thus, the market in LPSM firms is likely to be more illiquid than for other subs in the sample, resulting in a greater price impact of the selling by large-value institutions. This explanation is reinforced by the finding that the significant increase in holdings of small-growth institutions in small subs with low prior ownership (LPSM) is also associated with significant price movements during the +1 through +35 horizon.

\section{E. Temporary Price Pressures versus Downward Sloping Demand Curves}

Because we do find some limited evidence of price movements that are significantly associated with preference-induced institutional trading in the smallsub, low-prior-ownership partition, we perform additional analyses to assess whether the mean return results of Vijh (1994) and Brown and Brooke (1993) are more consistent with short-term price pressures or with long-term demand curve effects. We perform several different tests similar to Kaul et al. (2000). First, we examine mean weekly returns and mean cumulative returns for the week of the spin-off and the following 19 weeks. If the price movements are temporary, the week-1 positive (negative) returns that we observe for the parents (subs) should reverse, and cumulative returns should eventually equal zero. We also regress cumulative returns from week 2 through week $T$ (where $T$ ranges from 2 through 20) on week-1 returns. If price movements are completely temporary, then the regression coefficient should at some point be -1 .

In the case of the parents, we find evidence that is more consistent with permanent, rather than temporary, price movements. The mean return for week 1 is $3.7 \%(p<.01)$. The mean return for week 2 is $-0.88 \%(p=.03)$, indicating a slight price reversal. The cumulative returns are positive every week and are always significant at least at the $10 \%$ level, providing no evidence of significant price reversal. The coefficients in the return reversal regressions are never significant, again providing no evidence of price reversal.

We find more evidence of price reversals in the subs. Our examination of weekly returns shows the week-1 to week-7 returns are consistently negative (although not always significant). The week-8 return is a significant $1.26 \%$. Weeks $10-15$ are consistently positive, but not significant. Return reversal regressions also provide evidence of a partial reversal. The coefficients are consistently negative, though not significant, for the regressions where $T$ is week 2 through the regressions where $T$ is week 7 . The coefficient of the regression where $T$ is week 8 is significantly different from zero at the $5 \%$ level. However, it is also significantly different from -1 , indicating that although there is some price reversal in the subs, it is only a partial reversal. Overall, the abnormal price movements for parent and subs after spin-offs are more consistent with long-term demand effects than with short-term price pressures. 


\section{Summary and Conclusions}

In this article, we examine institutional investor demand for spin-off sub and parent stocks to assess the impact of fiduciary restrictions and precomittments to investment strategies on temporary price pressures after spin-off transactions. Consistent with predictions, the empirical results strongly indicate that differences in institutional investor preferences explain changes in institutional holdings of both parents and subs after spin-offs. Nevertheless, we find only very limited evidence of price movements associated with changes in institutional investor holdings. We find evidence that purchases of small post-spinoff parents by small-growth institutions with low prior ownership leads to economically meaningful positive abnormal returns on the effective date of the spin-off, which is consistent with Vijh's (1994) clientele explanation for the abnormal ex date return in spin-off transactions. However, this relation does not fully explain the effective date abnormal return, and this association is not evident in any other types of spin-off transactions. In addition, we find very little evidence to support the claim that significant liquidation of institutional holdings that are subject to stringent fiduciary standards or adhere to large-value strategies are associated with the temporary downward price pressures in subs reported in Brown and Brooke (1993).

Overall, our results suggest that while the significant changes in institutional holdings around spin-offs are associated with abnormal trading volume levels immediately after the spin-off, the large volume of institutional investor rebalancing generally does not lead to price increases (declines) in the parent (sub). We find evidence of price movements associated with preference-induced institutional trading around spin-offs only in extreme cases, such as when the sub is small and prior ownership in the firm is low. Even in this case, the associated price movement does not account for a substantial portion of the abnormal return around the spin-off.

\section{Appendix}

This appendix presents the definitions of the variables used to classify institutions by investment styles. The characteristics are calculated at the end of each calendar quarter for every institution on the Spectrum database. The quarterly values are averaged over all quarters available for the calendar year to get end-of-year average values of each characteristic for each institution. These average annual values are used in the subsequent factor and cluster analyses.

TABLE A1 Institutional Investor Portfolio Characteristics

\begin{tabular}{ll}
\hline Variable & \multicolumn{1}{c}{ Definition } \\
\hline $\begin{array}{l}\text { Weighted average market capitalization } \\
\quad \text { WAMC) }\end{array}$ & $\left(\sum \mathrm{w}_{k t} \mathrm{MC}_{k t}\right) / \mathrm{w}_{k t}$ \\
Percent holdings in S\&P 500 firms (WASP) & $\left(\sum \mathrm{w}_{k t} \mathrm{SP}_{k t}\right) / \mathrm{w}_{k t}$ \\
Weighted average time listed (WATIME) & $\left(\sum \mathrm{w}_{k t} \mathrm{TIME}_{k t}\right) / \mathrm{w}_{k t}$ \\
Weighted average price per share (WAPRC) & $\left(\sum \mathrm{w}_{\mathrm{kt}} \mathrm{PRC}_{k t}\right) / \mathrm{w}_{k t}$
\end{tabular}


TABLE A1 (Continued)

\begin{tabular}{|c|c|}
\hline Variable & Definition \\
\hline Weighted average earnings growth (WAEGR) & $\left(\sum \mathrm{w}_{k t} \mathrm{EGR}_{\mathrm{kt}}\right) / \mathrm{w}_{k t}$ \\
\hline Weighted average sales growth (WASGR) & $\left(\Sigma \mathrm{w}_{\mathrm{kt}} \mathrm{SGR}_{k t}\right) / \mathrm{w}_{k t}$ \\
\hline Weighted average beta (WABTA) & $\left(\Sigma \mathrm{w}_{k t} \mathrm{BTA}_{k t}\right) / \mathrm{w}_{k t}$ \\
\hline $\begin{array}{l}\text { Weighted average standard deviation of returns } \\
\text { (WASTD) }\end{array}$ & $\left(\Sigma \mathrm{w}_{k t} \mathrm{STD}_{k t}\right) / \mathrm{w}_{k t}$ \\
\hline $\begin{array}{l}\text { Weighted average earnings-to-price ratio } \\
\text { (WAEP) }\end{array}$ & $\left(\Sigma \mathrm{w}_{k t} \mathrm{EP}_{k t}\right) / \mathrm{w}_{k t}$ \\
\hline Weighted average dividend yield (WADP) & $\left(\Sigma \mathrm{w}_{k t} \mathrm{DP}_{k t}\right) / \mathrm{w}_{k t}$ \\
\hline Weighted average book-to-price ratio (WABP) & $\left(\Sigma \mathrm{w}_{k t} \mathrm{BP}_{k t}\right) / \mathrm{w}_{k t}$ \\
\hline $\begin{array}{l}\text { Percent holdings in firms with } 5 \text { consecutive } \\
\text { years of earnings growth (WADUP) }\end{array}$ & $\left(\Sigma \mathrm{w}_{k t} \mathrm{DUP}_{k t}\right) / \mathrm{w}_{k t}$ \\
\hline $\begin{array}{l}\text { Weighted average S\&P stock rating } \\
\text { (WARATE) }\end{array}$ & $\left(\Sigma \mathrm{w}_{k t} \operatorname{RATE}_{k t}\right) / \mathrm{w}_{k t}$ \\
\hline $\begin{array}{l}\text { Percent holdings in firms with positive earn- } \\
\text { ings (WAPED) }\end{array}$ & $\left(\Sigma \mathrm{w}_{k t} \mathrm{PED}_{k t}\right) / \mathrm{w}_{k t}$ \\
\hline Weighted average debt-to-equity ratio (WADE) & $\left(\Sigma \mathrm{w}_{k t} \mathrm{DE}_{k t}\right) / \mathrm{w}_{k t}$ \\
\hline
\end{tabular}

where

$\mathrm{w}_{k t}=$ Portfolio weight (shares held times stock price) in firm $k$ at quarter $t$

$\mathrm{MC}_{k t}=\log$ of market capitalization of firm $k$ at quarter $t$

$\mathrm{SP}_{k t}=1$ if firm $k$ is on the S\&P 500 and 0 otherwise

$\mathrm{TIME}_{k t}=$ Number of days listed on CRSP tape prior to quarter $t$ for firm $k$

$\mathrm{PRC}_{k t}=$ Price per share of firm $k$ at quarter $t$

$\mathrm{EGR}_{k t}=$ Geometric mean earnings growth for 3 years prior to quarter $t$ for firm $k$

$\mathrm{SGR}_{k t}=$ Geometric mean sales growth for 3 years prior to quarter $t$ for firm $k$

$\mathrm{BTA}_{k t}=$ Market model beta of firm $k$ estimated over 36 months prior to quarter $t$

$\mathrm{STD}_{k t}=$ Standard deviation of returns of firm $k$ estimated over 36 months prior to quarter $t$

$\mathrm{EP}_{k t}=$ Earnings-to-price ratio of firm $k$ at quarter $t$

$\mathrm{DP}_{k t}=$ Dividend-to-price ratio of firm $k$ at quarter $t$

$\mathrm{BP}_{k t}=$ book-to-price ratio of firm $k$ at quarter $t$

DUP $_{k t}=1$ if firm $k$ has 5 consecutive years of earnings growth and 0 otherwise

RATE $_{k t}=\mathrm{S} \& \mathrm{P}$ stock rating $(9=\mathrm{A}+, 0=$ not rated) of firm $k$ at quarter $t$

$\mathrm{PED}_{k t}=1$ if firm $k$ has positive earnings at quarter $t$ and 0 otherwise

$\mathrm{DE}_{k t}=$ Debt-to-equity ratio of firm $k$ at quarter $t$

\section{References}

Badrinath, S.; Gay, G.; and Kale, J. 1989. Patterns of institutional investment, prudence, and the managerial safety-net hypothesis. Journal of Risk and Insurance 56 (December): 605-29.

Bennett, J.; Sias, R.; and Starks, L. 2000. Greener pastures and dynamic institutional preferences. Working paper. Austin: University of Texas.

Brown, K., and Brooke, B. 1993. Institutional demand and security price pressure: The case of corporate spin-offs. Financial Analysts Journal 49 (September-October): 53-62.

Bushee, B. 1998. The influence of institutional investors on myopic R\&D investment behavior Accounting Review 73 (July): 305-33.

Carson Group. 1995. The 1995 International Who's Who of Institutions and Mutual Funds. New York: Carson.

Chan, L., and Lakonishok, J. 1993. Institutional trades and intraday stock price behavior. Journal of Financial Economics 33 (April): 173-89. 
Cusatis, P.; Miles, J.; and Woolridge, J. 1993. Restructuring through spin-offs: The stock market evidence. Journal of Financial Economics 33 (June): 293-311.

Del Guercio, D. 1996. The distorting effect of the prudent man law of institutional equity investments. Journal of Financial Economics 40 (January): 31-62.

Falkenstein, E. 1996. Preferences for stock characteristics as revealed by mutual fund portfolio holdings. Journal of Finance 51 (March): 111-35.

Gompers, P., and Metrick, A. 2001. Institutional investors and equity prices. Quarterly Journal of Economics 116 (February): 229-59.

Hair, J., Jr.; Anderson, R.; Tatham, R.; and Black, W. 1995. Multivariate Data Analysis. 4th ed. Englewood Cliffs, N.J.: Prentice-Hall.

Harris, L., and Gurel, E. 1986. Price and volume effects associated with changes in the S\&P list: New evidence for the existence of price pressures. Journal of Finance 41 (September): 815-29.

Kaul, A.; Mehrotra, V.; and Morck, R. 2000. Demand curves for stocks do slope down: New evidence from an index weights adjustment. Journal of Finance 55 (April): 893-912.

Krishnaswami, S., and Subramaniam, V. 1999. Information asymmetry, valuation, and the corporate spin-off decision. Journal of Financial Economics 53 (July): 73-112.

Lakonishok, J.; Shleifer, A.; Thaler, R.; and Vishny R. 1991. Window dressing by pension fund managers. American Economic Review 81 (May): 227-31.

Lang, M., and McNichols, M. 1997. Institutional trading and corporate performance. Working paper. Stanford, Calif.: Stanford University.

Lev, B. 1991. Identifying the preferences of institutional investors and implementing a strategy for change. Working paper. Berkeley: University of California.

Lynch, A., and Mendenhall, R. 1997. New evidence on stock price effects associated with changes in the S\&P 500 index. Journal of Business 70 (July): 351-83.

O'Barr, W., and Conley, J. 1992. Fortune and Folly: The Wealth and Power of Institutional Investing. Homewood, Ill.: Business One Irwin.

Ofek, E., and Richardson, M. 2000. The IPO lock-up period: Implications for market efficiency and downward sloping demand curves. Working paper. New York: New York University.

Shleifer, A. 1986. Do demand curves for stocks slope down? Journal of Finance 41 (July): 579-90.

Tkac, P. 1999. A trading volume benchmark: Theory and evidence. Journal of Financial and Quantitative Analysis 34 (March): 89-114.

Vijh, A. 1994. The spin-off and merger ex-date effects. Journal of Finance 49 (June): 581-609. 